\title{
Theological Mediation of the Current Alterity in Western Naturalisation Policy, Immigration Control and Global Diaspora
}

\author{
Ugonna Chimnonyerem Nkwunonwo ${ }^{1}$, Cosmas Ikegwuruka ${ }^{2}$ \\ ${ }^{1}$ Department of Geoinformatics and Surveying, University of Nigeria Enugu Campus, Enugu, Nigeria \\ ${ }^{2}$ Almond Legals-Immigration, Asylum and Human Rights Lawyers \& Researchers, London, UK
}

Email address:

ugonna.nkwunonwo@unn.edu.ng (U. C. Nkwunonwo), almondlegals@yahoo.co.uk (C. Ikegwuruka)

\section{To cite this article:}

Ugonna Chimnonyerem Nkwunonwo, Cosmas Ikegwuruka. Theological Mediation of the Current Alterity in Western Naturalisation Policy, Immigration Control and Global Diaspora. International Journal of Law and Society. Special Issue: Immigration Control, Citizenship, the Interplay of Sovereignty and the Vicissitudes of the Hostile Environment. Vol. 3, No. 1, 2020, pp. 32-38. doi: 10.11648/j.ijls.20200301.15

Received: February 13, 2020; Accepted: March 11, 2020; Published: May 12, 2020

\begin{abstract}
This paper explores how theological exegesis of Genesis 20 vs. 1-18 texts, and the book of Ruth can be applied in the context of mediating the harsh western citizenship and naturalisation policy, immigration rules and the global diaspora, bearing in mind the key prospects of theological reflection and how they find expressions in addressing problems within the complex human society. The primacy of Biblical texts and narratives as a tool for interrogating and addressing issues of concern within the diverse human, political, economic and socio-cultural contexts is incontrovertible. The overriding intention of hermeneutics in relation to theological pedagogy and dialectics has in fact been to determine how the reading and interpretation of literary works in general and Biblical texts and narratives in particular, have shaped and transformed patterns and outcomes of human behaviours. This is in terms of actions and responsibility - how human beings understand their world, the diversities and dimensions of their experiences, how they express interpersonal, intertribal, interreligious, interregional and international relationships, and how they are able to resolve conflicts and crises that are part and parcel of their experiences and interactions. Thus, it is believed that theological framing of ideas, and logical postulations especially in synthesising knowledge and transforming critical understanding of concepts, paradigms and theories from a synergy of interdisciplinary discourse can be useful in addressing global ethnographic alterity. Indeed, interdisciplinary discourses that couple environmental sciences, theology and law have established a long presence as an academic discourse. However, the increasing manifestations of alterity in immigration and naturalisation policies within the western world raises key question in relation to how to bring to bear the cultural, political, legal, environmental and moral significance of the meanings that are being derived from the texts and narratives that make up the Bible.
\end{abstract}

Keywords: Alterity, Theological Reflection, Immigration Policy, Western Naturalisation, Global Diaspora, Human Society, Bible Texts, Interdisciplinary Discourse

\section{Introduction}

Alterity - anomaly or outliers or 'disorder of the original order/ arrangement/ structure/ system of things' - within societies can be likened to situations that pose significant challenges to human existence and interaction with one another at levels that are largely variable. Familiar examples of these situations which appear to have been entrenched and problematized within a global context include diaspora, forced migration and naturalisation policies. These are issues and concerns which share multi-disciplinary, multicultural and intergovernmental boundaries. Within the academy of nationalism, worldwide migration and ethnography, the conceptualization of diaspora, forced migration and western naturalisation policy was originally based on the dispersal of human population from their original habitation to a new environment. In other words, it can be said to simply imply the creation of refugees worldwide. This seminal idea has so far been sufficient to peddle and propagate the critical issues surrounding refugeeism, but it has also created a form of 
fuzziness in the taxonomical précis of refugees especially in the present-day context.

For global diaspora, the definition is derived from the original Greek semantics which refers to the dispersal of a population through colonization [1]. Forced migration according to International Association for the Study of Forced Migration (IASFM) is the movements of refugees and people internally displaced by conflicts, disasters, famine, or and in the most case justifiable fear of persecution because of race, religion, nationality, political opinion or membership of a particular social group (UNHCR ${ }^{1}$, 1951; [2]). Naturalisation includes the whole legal act or process by which a non-citizen of a country acquires citizenship or nationality of that country. By law, this process should be simple and straight forward and aimed at assisting migrants who are fleeing their home country to integrate freely and more quickly. But the antecedents, the present circumstances and evidence from most published articles (see for instance; [3]) have shown in the UK for example, this process is hard, unbearably long and exacts huge financial impacts for quite a number of migrants who are now in the dilemma of floating in the UK and also not having anywhere else to go. This raises a question as to why western naturalisation is a challenging process.

It is unarguable that most of those who seek asylum in the context of international protection or wanting to naturalise within the western enclave might be victims of human trafficking. However, dealing with the present alterity, one might find a way to fit human trafficking issues into the present discussion, or simply consider the means to address the growing menace of human trafficking across Africa and Asia. Human trafficking, considered to be a violation of human rights by the International Labour Organization (ILO), is described as the willy-nilly commercialization of human beings, especially women and children, for somewhat sinister purposes such as forced labour, sexual servitude, forced marriage, organ extraction, surrogacy, etcetera [4]. In certain cases, with particular reference to Canada, human trafficking is considered as a form of immigration into countries and new environments that victims often fantasize about [5]. This notion speculates some kind of consent from the victims being transported illegally; who, on arrival to destination countries, would then legitimize their status as refugees fleeing oppressive and brutal countries of origin.

Given the above background, this paper explores how Biblical texts and narratives can provide the requisite clarifications, in terms of the underlying factors, impacts within the human society and possible panacea, for diaspora, forced migration and general concept of naturalisation. Genesis 20 vs. 1-18 and Ruth are being considered to defuse the tension implicit in these global issues, which have, over the years, posed severe challenges to human cultures and societies. Conforming to the view held by many previous

1 UNHCR - The United Nations High Commissioner for Refugees. Its 1951 Refugee Convention, which was extended by 1967 protocol, provides the key underpinnings and meaning of a refugee. authors including Graham \& Mackenzie [6], Watson [7], Rowland \& Roberts [8] and Greene \& Robinson [9], an attempt was made to ensure that this essay was limited primarily with theological issues raised by the narratives within a contemporary cultural and social-political context. Time often seems to create an unusual degree of dissonance between Biblical narratives and the corresponding events in present-day contexts. However, there is a wealth of resonances, divine feelings, euphemisms, metaphors, binarisms, particularism and universalism, syncretism and infusions of foreign talents and traditions; etcetera packed within Biblical texts and narratives, and these have been exploited in discussing these global issues. It is posited that whilst most political affiliations and discussions - with academic research - play significant roles in tackling these global issues, theological reflection must be grasped as the balm which heals the ailing human heart, the indisputable heart and foundation of the human problem.

\section{Resolving the Conflicts of Ideas in Diaspora and Human Migration}

There seems to be a diversity of views in extant academic debates and political dialogues relating to diaspora. And so, the true nature of diaspora and human migration have been feebly clarified and spotlighted, resulting in a situation whereby the obvious problems with especially forced migration and refugee's situation being generalized as a mere irony, metaphor or even rhetoric and a contradiction of the true situation. In the UK for an instance, the Tabloid Media have largely been accused of feeding the public domain with a 'relentless negativity' ${ }^{2}$ of the true nature of refugees situation which also demonstrates a high level of ignorance on the part of the Border Agency and British authority that especially seems to formulate immigration policies and guidelines on the basis of untrue statistics and anecdotal evidence. Meanwhile, Africans and Asians, who apparently form the majority of the refugee population and victims, consider the issue of global diaspora, migration and human trafficking from a more vicious and antagonistic point of view. All these suggest that the world in general which includes political, religious, economic and human agencies have not fully come to terms with the most abject situation whereby it desperately ails.

Contemplating this diversity of views, Cohen [10] argues that the changing regimes of diaspora from its original paradigm and framework to the present underpinning and construct, suggest among other things, the necessity of a new ideology so as to be able to offer an even more overarching meaning and pragmatic solution. This will incorporate the contemporary challenges facing the dispersals of human population in general, and global diaspora in particular. With the current trend indicating that the number of those who have been forced to flee their countries, homes, families and

2 Smith, D. (2016: 13). How do we respond? Refugee stories: seven personal journeys behind the headlines. Watford: Instant Apostle. 
friends, in addition to exponential growth of human trafficking with its complex challenges, it is now needful to consider more academic and political dialogues even as it is also more crucial and instructive to engage with deep moral discussions. This will help to clarify, by reinterpretation of concepts, the existential and true situations of global diaspora, forced migration and naturalisation without pitting them over and above all other issues within the human societies. Then, within the framework of western culture and western asylum systems, protection for refugees and victims of human trafficking can become issues of more concern to cultural and theological response than just political dialogue.

\section{Diaspora and Migration: A Divine Strategy}

"If there were no night, we would not appreciate the day, nor could we see the stars and the vastness of the heavens. We must partake of the bitter with the sweet. There is a divine purpose in the adversities we encounter every day. They prepare, they purge, they purify, and thus they bless."

This moving quote by James E. Faust ${ }^{3}$ articulates the actuality of divine intention and underpinnings in various human experiences. This is without doubt a very argumentative issue which might be debunked in the light of extreme sufferings, and traumas. It might portray God as brutal, bringing pains and sufferings to the people and at the same time showing insensitivity to such pains and sufferings. Or perhaps one might be forgiven to ask, 'what kind of a God would $\mathrm{He}$ be to perfect His purpose in the life of His subjects by taking them through pains and troubles, sicknesses, conflict within communities, displacement, and even death?' "Grieve" they say "is a form of ritual"; therefore, does God relish our grief as a gratification for his being? Although these speculations and postulations do not undermine the divine persona of God from the Christological premise of theology as there is something clearly revealing whereby light can be perceived at the end of every tunnel. This is what either the story of Abraham and Sarah in Gerar, or Naomi and her family in Moab, or even Ruth in Bethlehem highlights about diaspora, forced migration and human trafficking. The texts from Genesis 20 vs. 1-18 and the book of Ruth presents six prominent characters - Abraham, Sarah, Naomi, Ruth, Abimelech and Boaz - who form the basis for considering global diaspora, forced migration and human trafficking in the present essay.

Whilst there is a wealth of theological reflection, commentaries, letters and homilies on the lives of these individuals, only few discussions have epistemologically

\footnotetext{
3 James E. Faust (July 31, 1920 - August 10, 2007) was an American cleric, lega practitioner and politician. He served in the Church of Jesus Christ of Latter-day Saints as a Second Counsellor in the First Presidency from 1995 until his death. He was a man of much faith in God whose work revolved around the primacy of light in world full darkness. His three most important publications include: Reach out for the light (1990), The true gifts of Christmas (2002), and Finding light in a dark world (2004)
}

focused on how their experiences resonate with diaspora, forced migration and naturalisation policy. Holdsworth [11] provided a model by which Old Testament (OT) texts can be connected to contemporary experiences and this is critical in understanding characters of OT within a subjective paradigm. Based on Holdsworth's model, the present narratives motivate one to ask where each of these characters stand in the spectrum of diaspora. For Abraham, Sarah and Naomi, the answer is in the affirmative, as there was occasion in which they had to flee their homeland in search of a safe haven in another country. Naomi with her family (her husband Elimelech and two sons - Mahlon and Chilion) fled to Moab due to a terrible famine, hunger and starvation in Bethlehem. This situation is more obvious considering the opening phrase of the book of Ruth, 'a time when judges ruled', which Schlanger [12] treated as an allegory for political insecurity - a situation that makes Naomi's family vulnerable, suggesting a more desperate ground for them to flee for safety. It is not clear from Genesis 20 vs. 1-18 why Abraham and Sarah had to flee to Gerar. However, Biblehub ${ }^{4}$ presents popular Bible commentaries, which have argued on a number of factors that could have necessitated the escape. Some of these commentaries are:

[...] Because he could not bear the stench of the sulphurous lake, the cities of Sodom and Gomorrah were become; and others, the scandal of Lot's incest with his daughters, which prejudiced the idolatrous people in those parts more against the true religion; neither of which are likely, by reason of the distance; but the better reason seems to be, that it was so ordered in Providence that he should remove from place to place, that it might appear that he was but a sojourner in the land" - Gill's expository of the entire Bible:

[...] but the total separation between him and Lot, and the awful overthrow of Sodom and Amorah in the vicinity, may have loosened his tie to Hebron, and rendered it for the present not an agreeable place of residence" - Barnes notes on the Bible.

[...] whether terrified by the destruction of Sodom, or, as some of the Jewish writers say, because he was grieved at Lot's incest with his daughters, and the reproach which the Canaanites cast upon him for his kinsman's sake" - Benson commentary.

[...] As he had been commanded to traverse the whole land... It was the rule of his life to move from place to place, both on account of his cattle, and also because by so doing he was taking possession of the country " - Ellicot's commentary for English readers".

Clever extrapolations from these commentaries would associate the duo's emigration to Gerar with a divine arrangement and a sense of prejudice and persona non grata which Abraham felt with the scandal of Lot's sexual irresponsibility with his daughters. Whilst the ontology of a divine arrangement is hard to substantiate, prejudice breeds discrimination and in extreme cases can cause a violation of

4 Biblehub is an online bible commentary source: http://biblehub.com/commentaries/genesis/20-1.htm. 
fundamental human rights. These are grounds for diaspora and forced migration as stipulated in the human rights acts and protocols (ibid).

Abimelech and Boaz occupied a connectivity position in the entire narratives, and perhaps in the framing of the divine strategy. Their roles underline marriage as a pivotal aspect of migration, but also as a sine-quo-non in God's divine plan. For Abimelech, marrying Sarah is a manipulative, hegemonic and one-sided proposal. It was going to be a forced marriage, which is one of underlying potentials of human trafficking. Marriage is meant to be consensual, but Sarah was to marry Abimelech against her wish, as an indemnity to keep Abraham alive - a political quid pro quo. As it lacks any form of consensual support and credibility, the AbimelechSarah marriage move reveals something about modern day slavery which is akin to human trafficking. It is not obvious the intent of the Abimelech-Sarah marriage, but this form of practice in Gerar sheds some light on the abuse, exploitations, possible fears and apprehensions which migrants experience in the places where they flee for safety. Smith [13] tells touching stories of tragic situation which confront asylum seekers in the UK. One of those stories, which is perhaps most pathetic, unearths the ordeal of a young man who has had to work for twelve hours in a day for just $£ 25$ - in the so-called black economy $y^{5}$. In fact, lying and dishonesty became his only tools to survive which is much like what Abraham did in Gerar. Whichever form it represents - the section 4 accommodation ${ }^{6}$ or little weekly handouts through an 'Azure payments card' that could only afford few stuffs from designated shops, or lingering legal issues or the fears of being sent back to the country where one is fleeing, there is a provocative degree of dehumanization and trauma that people who are fleeing for refuge have had to contend with. This is what the life of Abraham and Sarah in Gerar reveals. Reading these texts in context of global diaspora should make anyone aware that unlawful behaviours which are often exhibited by people fleeing their countries of origin oftentimes show the level of struggle and adaptation for survival.

Boaz's marriage to Ruth contrasts vividly with Abimelech's to Sarah. Boaz had no earlier intention; in fact, the narrative indicates that Boaz had no prior knowledge or impression of Ruth. Boaz was not even the nearest kin to Elimelech, so he did not have an immediate customary entitlement to marry Ruth. Boaz-Ruth marriage was not just about the unwillingness of the right next-of-kin or the willingness of Boaz to redeem a legacy for Elimelech; it alludes to something designated for the future. It totally reveals the divine feelings and strategy evoked in context of Ruth's migration to Bethlehem, and perhaps how it applied to global diaspora and migration generally. It is clear from the

\footnotetext{
5 The section of a country's economic activity which is unrecorded and untaxed by its government.

6 This is a temporary full-board or self-catering accommodation provided under section 98 of the Immigration, \& Asylum Act 1999-an Act that provide for the welfare of asylum seekers in the UK whilst waiting for a decision on their application.
}

narrative that Boaz was a man of good standing, wealthy and generous, kind, merciful and willing to show hospitality to the poor and destitute regardless of social, political or religious status. In a way his life resonates with Jesus' teaching in the Gospels, and challenges the present immigration policy and guidelines, of the West as well as the political cynicism surrounding global diaspora. What could have been a better ancestry for the future Messiah than the one specked with kindness and love? From the fall of man, God set out on a mission for restoration, and throughout the OT, it was clearly illuminated how God chose, at random, pieces of tools - perhaps human agencies and dramatic events such as the flood, destruction of Sodom and Gomorrah, etcetera - to accomplish this all-important mission.

Interestingly, the Patriarchs, Noah, Moses, Joshua, the Judges were all part of this human agencies. Ruth was to play a pivotal role in this mission; so, her chastity, kindness, compassion, love and relationship to Naomi and even marrying Boaz were all needed for the ancestral line of the future messiah who was to come in human form. Arguably, it could have been any other lady, but whilst it is hard to understand why Ruth was foregrounded in this narratives, the divine strategy in human migration is obvious, which therefore makes Ruth's migration to Bethlehem something of interest in a way to understand the future and how it entangles with marriage, human kindness, moral values, love and hospitality within the context of global diaspora and forced migration.

\section{Societal Culpability and the Ailing Human Heart}

Whether it was Abraham and Sarah in Gerar, or Naomi and her family in Moab, or even the present-day migration episodes, the defining moments of human dispersal often come at such times when people begin to feel a sense of brutality in and alienation from their original home of residence. This is defined by situations characterised by the following: lack adequate protection and assistance, a lingering ethnic and tribal conflicts, a high degree of inequality especially in accessing natural resources, comatose economic and living conditions, and a provocative degree of human rights abuses [14]. Ruth's migration to Bethlehem, unlike Abraham, Sarah and Naomi with her family, was necessitated by her kindness and willingness to continue her life in an entirely new environment and culture. In a sense, this reflects the people who become immigrants in the present-day context due to organ donation, charity and voluntary assignments or perhaps marriage. Whilst migration from Ruth's point of view cannot be explained away from the point of view of human agency, the other causes of migration can be mitigated by responsible agencies within human societies. Therefore, if blames must be placed where they belong, the human society, which fails to provide the basic necessities of life - human equality in all forms and political 
stability - is very highly culpable for diaspora, forced migration and human trafficking. As scholars have argued, human trafficking, considered pervasive and a clandestine form of movement into many western cultures, leaves as its main culprit, structural conditions (socio-economic and political) that have been consistent especially in Africa and Asia [5, 15].

In Nigeria, anecdotal evidence suggests that human trafficking also takes the form of baby factory, describing criminal activities involving pregnant women and girls who give up their new-borns in an outright sale or illegal adoption for financial reasons [16]. Poverty, food insecurity and unemployment have been largely underlined. Stigmatization which comes from the society against teenage pregnancy and couples with infertility issues is also a major factor [17]. Genesis 20 vs. 1-18 and the book of Ruth underline the societal culpability in human dispersal, although the narratives do not offer immediate solution. However, it suggests that a possible way to ease migration crises is for authorities and institutions at the global context not to allow politics and media fantasies outweigh considerations on how to deal with brutalities, structural conditions and other possible factors which cause people to flee their localities and countries of origin.

Whilst culpability of the society lies at one end of the spectrum, the state of human heart complements the rest of the migration spectrum. In the present narratives, love, kindness, chastity, generosity, deceit, openness, vulnerability, repentance, brokenness, and forgiveness are all depicted, taking as a whole, the lives of the characters foregrounded in the narratives. With reference to the critique and cultural transformation of the Bible, one might be prompted to ask how these factors assist in our reflection and theologizing of diaspora. In actual fact, the human heart is ailing as a result of mostly deceit, a lack of love and of kindness in relation to immigrants' countries of origin, and this might suggest that in dealing with what ails the human hearts, we might as well be able to deal with the structural causes and other drivers of global diaspora, forced migration and human trafficking. Furthermore, from a theological point of view, people of a diverse religious, cultural and political origin can live together if there is a sufficient sense of brokenness, openness, forgiveness and repentance.

\section{Binarism and Euphemism of the Lived Reality}

Genesis 20 vs. 1-18, the book of Ruth and indeed the present global diaspora, forced migration and human trafficking episodes seem to tell something about binarism, particularly of freedom and slavery, of elitism and pluralism, and of civilization and savagery. Abraham and Sarah were considered as slaves when they got into Gerar which is why Abraham was uncertain about his life and with Sarah had to equivocate in order to survive. Ruth was an outcast when she arrived in Bethlehem which mainly was the reason why the nearest kinsman to Elimelech did not redeem her. These scenarios are typical of immigration, and are true in many UK and western universities, where students are being classified as British/European Union (EU) and International, and assigned fee status based on this binary taxonomy. Why and how any policy would dispose international students to a higher tuition than the rest of the students, though quite daunting, is not the main concern of this essay. However, in a system where everyone is subject to the same teaching and academic exercises, such a policy is discriminatory, alienating and intolerable. This binarism also appears in the resident labour market test $(R L M T)^{7}$ whereby a migrant cannot be offered a job even if he or she is the most qualified applicant, as long as a British or EU applicant is willing to take up the position. Now when you consider the use of the terms; 'equality' and 'diversity', in application pages of job positions, there is a feeling of euphemism or illusions of the lived reality for people in diaspora in the Western world.

There is also a binarism of good/bravery/kindness/compassion and evil, love and hatred, sorrow and joy, one choice and another revealed in the present narratives as the characters escape to join a new community wherein, they begin new lives. Abraham and Sarah embodied love and affection, but their marital harmony was nearly marred by the sadism and evil practice in Gerar. Similarly, Ruth typified a love story, but is also mingled with hatred. Parallel to the Cinderella story, which is meant to end with the phrase, "and they lived happily ever after", Ruth's journey to the messianic ancestry had many transitions Moabite, Jew, widow, wife, stranger, citizen, destitute, childless, mother and grandmother - all of which resonates with the binarism of love and hate. There was a binarism of sorrow and joy for Naomi who in the course of time experienced poverty, widowhood, loneliness, but in the aftermath had joy. There was also a binarism of one choice and another, first for Naomi when she left Bethlehem for Moab and then returned back later on. For Ruth, it was a decision to accompany Naomi to begin a new life in Bethlehem, and then for Orpah, it was yet another decision. These narratives, which clarify cultural diversity and the roles played by binarism in the evolution of human destiny, should be read with the mind to attempt the deconstruction of various forms of binarism by which people in diaspora are denied a good sense of wellbeing and community.

\section{Syncretism and Infusion of Needed Foreign Talent and Quality}

The English Oxford Living Dictionary ${ }^{8}$ defines syncretism as the amalgamation or attempted amalgamation of different

\footnotetext{
7 RLMT requires Tier 2 Sponsorship License holding employers to prove to UK Visas and Immigration that no UK citizen or EEA national is available for the role they want to assign to a Tier 2 visa worker.

8 The online version of this source is found on: https://en.oxforddictionaries.com/definition/syncretism.
} 
religions, cultures, or schools of thought. This explanation undergirds both religious and anthropological perspectives of cultural transformation which supposes that all religious (including Christianity and Islam) and cultural realities are subject to a combination of two or more essential components [18-19]. Plutarch, whose seminal work is considered to have laid the foundation of the concept of syncretism, refers to this concept in relation to how various Crete natives came to unite at the time when their survival was facing severe threats [20]. This is a critical part of the present narrative, as seen both in Abraham and Sarah in Gerar, and Ruth in Bethlehem. No country is complete in itself which is why international trades and collaborations are effective as bridge builders, to fill such resources and economic gaps. In the present narratives, Abraham brought the needed sense of guilt which was lacking in Gerar. With the immigration of Abraham and Sarah into Gerar, Elimelech, the king, and perhaps the entire community now come to the realization that their age-long culture and tradition was outrageous and needed to be atoned for. Ruth's migration to Bethlehem brought in the needed trait and foundation for Israel's throne and military strength, which would later be established in King David. In his commentary on the book of Ruth, Weinstein [21] argues that ascendancy to the throne was a process quite unfamiliar in Israel, but a commonplace in Moab, with her well established monarchy and military apparatus. Thus, with Ruth arriving Bethlehem and of course becoming the ancestress of the great king David, there is a syncretism, an infusion of the needed talent and quality for the monarchy and military strength which Israel would later embrace into the covenant and patriarchal privileges of Israel.

In a way, this also suggests particularism and universalism which Yosef Green in his essay on the book of Ruth argues that the Jews were able to maintain a particular identity whilst learning from other people [22]. This is quite an interesting realization in theologizing within contemporary times which is replete with misconceptions and fallacies about migration and diaspora. In his essay, Baily [23] refutes the idea that refugees constitute an economic burden for the countries that give them refuge, citing a study conducted by University of California and UC Davis (Home of the Aggies, an initiative with a distinctive mark at one of the top public universities in the United States. They are committed to change and providing solutions to a variety of problems) with the United Nations World Food Program which indicates that host country's economy can be substantially assisted by refugees receiving financial aids. This can be substantiated considering the human capital in the form of talents skills, and experiences that the majority of these refugees bring into their host countries [24].

\section{Conclusion}

This essay elucidated how Genesis 20 vs. 1-18 and the book of Ruth can be read in the context of global diaspora, forced migration and western naturalisation. Using resonances, divine feelings, binarism, euphemisms, syncretism and infusions of foreign talents and traditions; that are packed within the narratives, the present essay has demonstrated how people in diaspora, refugees, and victims of human trafficking can be made to have a good sense of wellbeing and community within the context of the Western culture. Although how these narratives are read - as a redemptive story, love story, divine story, or as a story which shadows the main issues within human dispersal — is crucial, theologizing within the contemporary time should emphasize the importance of such lessons as human kindness, mutuality and tolerance, repentance and forgiveness, all of which are fundamental to human coexistence regardless of religious, cultural, and socio-political diversity.

\section{References}

[1] Baumann, M. (2000). Diaspora: genealogies or semantics and transcultural comparison. Numen, 47 (3), 313-37.

[2] Muggah, R. (2003). A tale of two solitudes: comparing conflict and development-induced Internal displacement and involuntary resettlement. International Migration, 41 (5), 531 .

[3] Ikegwuruka, C. (2018). Immigration detention and liberal democracies: Is it all about power or money; if money, why, if power, why not?. International Journal of Law and Management, 60 (5), 1126-1147.

[4] Gozdziak, E. M., \& Collett, E. A. (2005). Research on human trafficking in North America: A review of literature. International Migration, 43 (1-2), 99-128.

[5] Oxman-Martinez, J., Martinez, A., \& Hanley, J. (2001). Human trafficking: Canadian government policy and practice. Refuge: Canada's Journal on Refugees, 19 (4) 1-10.

[6] McKenzie, S. L., \& Graham, M. P. (Eds.). (1998). The Hebrew Bible today: an introduction to critical issues. Westminster John Knox Press.

[7] Watson, W. G. (2004). Classical Hebrew poetry: a guide to its techniques. A\&C Black.

[8] Rowland, C., \& Roberts, J. (2008). The Bible for sinners: Interpretation in the present time. Society for Promoting Christian Knowledge.

[9] Greene, C., \& Robinson, M. (2008). Metavista: Bible, Church and Mission in an Age of Imagination the church after postmodernity. Authentic Media 9, Colorado Springs, USA.

[10] Cohen, R., \& Van Hear, N. (2008). Global diasporas: An introduction. Routledge.

[11] Holdsworth, J. (2010). Lies, Sex and Politicians: Communicating the Old Testament in Contemporary Culture. Hymns Ancient and Modern Ltd.

[12] Schlanger, M. (2017). Illegal immigration and the book of Ruth: Shavuot offers an important lesson for politics today. Retrieved March 30, 2018, from Tablet: Observance: www.tabletmag.com/jewish-life-and-religion/235265/illegalimmigration-book-of-ruth. 
[13] Smith, D. (2016). How do we respond? Refugee stories: seven personal journeys behind the headlines. Watford: Instant Apostle.

[14] Wood, W. (1994). Forced migration: local conflicts and international dilemmas. Annals of the Association of American Geographers, 84 (4), 607-634.

[15] Wylie, G., \& McRedmond, P. (2010). Human trafficking in Europe: character, causes and consequences. Springer.

[16] Eseadi, C., Achagh, W., Ikechukwu-Ilomuanya, A., \& Ogbuabor, S. E. (2015). Prevalence of baby factory in Nigeria: an emergent form of child abuse, trafficking and molestation of women. International Journal of Interdisciplinary Research Methods, 2 (1), 1-12.

[17] Makinde, O. A., Olaleye, O., Makinde, O., Huntley, S., \& Brown, B. (2017). Baby factories in Nigeria: Starting the discussion toward a national prevention policy. Trauma, Violence, \& Abuse, 18 (1), 98-105.

[18] Lambropoulos, V. (2001). Syncretism as mixture and as method. Journal of Modern Greek Studies, 19 (2), 221-235.
[19] Pandian, J. (2006). Syncretism in Religion. Anthropos, 101 (1), 229-233. Retrieved from http://www.jstor.org/stable/40466631.

[20] Leopold, A. (2001). The architecture of syncretism: A methodological illustration of the dynamics of syncretism. Historical Reflections/Réflexions Historiques, 27 (3), 401-423.

[21] Weinstein, B. (2004). Naomi's mission: a commentary on the book of Ruth. Jewish Bible Quarterly, 32 (1), 46-50.

[22] Yosef, G. (2002). Universalism and/or Particularism. The Jewish Bible Quarterly, 30 (1), 3-10

[23] Bailey, P. (2016, June 20). Refugees can offer economic boost to their host countries. Retrieved April 16, 2018, from UC DAVIS: https://www.ucdavis.edu/news/refugees-can-offereconomic-boost-their-host-countries/.

[24] Sawyer, J. F. (Ed.). (2012). The Blackwell companion to the Bible and culture. John Wiley \& Sons. 